\title{
Effect of Audit Quality on Earnings Management in Insurance Companies in Nigeria
}

\author{
By Chizoba Mary Nwoye*, Alphonsus Sunday Anichebe ${ }^{ \pm}$\& \\ Ifeanyi Francis Osegbue
}

The main objective of the study is to determine the effect of audit quality on earnings management in insurance companies in Nigeria with special consideration on accruals and performance measures of earning manipulations using insurance companies in Nigeria. Preliminary analyses were conducted, such as descriptive statistics and correlation matrix. In analyzing the data, the study adopted panel multiple regression to identify the possible effects of audit quality on earnings management of financial institutions in Nigeria We interpreted fixed effect analysis after using Hausman test. The result shows that audit quality had a significant effect on earnings management. We conclude that longer stay of auditors in financial institutions increases accrual and performance manipulation. However, financial institutions audited by the Big 4 auditing firms are associated with less accrual and performance earnings manipulation while financial institutions that have executive and non-executive directors as members of audit committee have greater accrual and performance earnings manipulations. Higher number of financial experts in audit committee increases accrual manipulation while higher number of experts with accounting background in audit committee reduces performance manipulating. Finally, increase in auditors' fee leads to choices of using accounting methods to manipulate both accrual and performance earnings. Therefore, the study recommends that, financial institutions should have maximum number of years for auditors to stay. They should focus more on increasing the number of experts with accounting background in audit committees. Accounting bodies should regulate auditors' fee in line with the size of the financial institution. (JEL M42)

Keywords: Audit Fees, Audit Committee Independence, Audit Firm Size, Audit Quality, Earnings Management, Financial Literacy of Audit Committee Members, Length of Audit Tenure.

\section{Introduction}

Earnings management has remained a widely researched area in accounting for the last two decades; this is because it is assumed as the most important ethical issue facing the accounting profession. Several years after the collapse of Enron Corporation, the organization has continued to fascinate those interested in earnings management. Although Enron corporation is the most popular case of accounting disclosure failure in the world. According to Teoh, et al. (1998), we

*PhD Student, Chukwuemeka Odumegwu Ojukwu University, Nigeria.

${ }^{ \pm}$Associate Professor, Chukwuemeka Odumegwu Ojukwu University, Nigeria.

*Lecturer II, Nnamdi Azikiwe University, Nigeria. 
would expect financial institutions to manage earnings prior to public offering and when in financial distress. When there are some doubts about the reliability of a company's qualitative financial disclosure, we may turn our attention to the auditor's report. In theory, the auditing process is supposed to serve as a monitoring device that reduces management incentives to manipulate reported earnings, as well as to detect earnings manipulation and misstatements Amat, et al. (2014). Audit is a key contributor to financial stability and in other to re-establish trust and market confidence. The auditor is entrusted by law with the responsibility of conducting statutory audits and fulfilling an important role in offering an opinion on whether the financial statements are truly and fairly stated.

Many studies have been conducted on audit quality and earnings management because earnings manipulated has long been of interest to analysts, legislators, researchers, and other investment professionals such as Aliyu et al. (2015) in Nigeria; Gulzar and Zongjun (2011) in China, Dechow et al. (1996) in Pennyslyvia; Barbadillo and Aguilar (2009) in Spain and so on. Nigeria as a developing country has had its fair share of dishonest accounting disclosures such as the case of Cadbury Nigeria Plc in 2006; Afribank Nigeria Plc in 2006, Intercontinental Bank Plc in 2009; Enterprise bank in 2014 and others. The financial sector, which is a very sensitive part of the economy, has become the most exposed sector using discretion in preparing and reporting accounting information to external users, despite all regulatory measures and auditing processes. This has become major concern to stakeholders in Nigeria, giving rise to some questions like; (1) Why would a financial institution with healthy financial statement suddenly become sick after series of unqualified opinion by reputable auditing firm? (2) Does it mean that audit quality has lost one of its secondary aim to detect earnings manipulation? (3) Does auditing processes negatively or positively influence firms' operational practices? These have become issues that needs urgent attention.

Based on the above questions, the main objective of the study is to determine the effect of audit quality on earnings management. While specific objectives are to determine the effect of audit tenure, audit firm size, audit committee independence, financial literacy of audit committee members and audit fees on earnings management with special consideration to modified jones discretionary accrual and performance matching models. Studies such as, Aliyu et al. (2015); Adeniyi and Mieseigha (2013), Adeyemi et al. (2012), Nuraddeen and Hasnah (2015) and Olabisi et al. (2017) in Nigeria only looked at accruals assessment of earnings management without considering the relationship between accruals and performance of earnings manipulation in insurance companies. In this light, the following research null hypothesis were developed:

$\mathrm{H}_{1}$ audit tenure does not have any significant effect on earnings management;

$\mathrm{HO}_{2}$ audit firm size does not have any significant effect on earnings management;

$\mathrm{HO}_{3}$ audit committee independence does not have any significant effect on earnings management; 
$\mathrm{H}_{4}$ financial literacy of audit committee members does not have any significant effect on earnings management and

$\mathrm{H}_{5}$ audit fees does not have any significant effect earnings management

The paper covers insurance companies in Nigeria from the period of 20122017 using their annual reports from Nigeria stock exchange. The remaining sections of the paper are organized as follows. Section 2 briefly reviews empirical literature on audit quality and earnings management. It discusses the effect of the independent variables on the dependent variable. The research design is described in Section 3, while Section 4 presents and discusses the empirical findings. Section 5 provides a summary of the results, conclusion and recommendations.

\section{Review of Related Literature}

\section{Earnings Management}

Roychowdhury (2006), defined earnings management as departure from normal operational practices, motivated by manager's desire to mislead some stakeholders into believing that, certain financial reporting goals have been met in the normal course of operations while Aziatul et al. (2015) defined it as the use of discretion in preparing and reporting accounting information to external users by managers. Leuz et al. (2003), sees it as the alteration in firms reported economic performance by managers either to mislead some stakeholders or to influence contractual outcome with them. Sankar and Subramanyam (2001), is of the opinion that, earnings management means 'taking advantage of the flexibility in the choice of accounting methods to indicate the management decision-making on future cash flows, while Hepworth (1953), defined it as smoothing the amplitude of periodic net income fluctuations. Schipper (1989) stated that, earnings management means 'disclosure management' in the sense of a purposeful intervention in the external financial reporting process, with the intent of obtaining some private gain.

Jiraporn et al. (2008), sees earnings management as distortions in financial reports, which occurs when there is a misalignment of incentives between managers and shareholders. This could drive the managers to exercise the flexibility of accruals accounting to adjust earnings opportunistically. While Yaping (2005) stated that, the employment of earnings management requires the manager's judgment to change the accounting estimation and policies, this right given to managers to use their judgment and discretion in accounting gives the managers the power to choose which allowable accounting method, policies and estimate encourages earnings manipulation because they are covered within the accounting law. Finally Healy and Wahlen (1999), are of the opinion that, earnings management occurs when managers use judgment in financial reporting and in structuring transactions to alter financial reports, either to mislead some stakeholders about the underlying economic performance of the company, or to influence contractual outcomes that, depend on reported accounting numbers. 


\section{Audit Quality}

DeAngelo (1981), defined audit quality as "the joint probability that, an auditor will both discover and report a breach in the client's accounting system. The discovery of a misstatement measures quality in terms of auditor's knowledge and ability, while reporting the misstatement depends on the auditor's incentives to disclose." This definition is appropriate for external financial statement audits; it can be expanded to include other types of auditors (e.g., internal auditors) and audits (e.g., compliance and operational audits). Seyyed et al. (2012) provides further explanation that, audit quality could be a function of the auditor's ability to detect material misstatements and reporting the errors. Together with other similar definitions, they all emphasized on two of the most important aspects of audit quality, namely auditor ability or auditor effort, and auditor independence. Zehri and Shabou (2011) asserted that, high quality auditors are more likely to discover questionable accounting practices by clients and report material irregularities and misstatements compared with low quality auditors.

According to Watkins, et al. (2004), financial reporting credibility is partially reflected in the confidence of users in audited financial reports. This is also noted by Levitt (2000), that the perception of audit quality helps role in maintaining confidence in the integrity of financial report. The higher the perceived audit quality, the more credible the financial statements.

\section{Theoretical Framework}

The study was anchored on the stakeholder's theory of corporate governance developed by Edward Freeman in the 1980s and signaling theory developed by Akerlof (1970) The stakeholder's theory argues that, a company should be managed in the interest of its entire stakeholder. The interest of the stakeholder include, the interest of the shareholders and other direct and indirect stakeholders such as, suppliers and creditors who have direct interest in the organization and supplies to the company on credit, based on their performance and investors who eventually invest their money in the company based on the audited report of the independent auditors and the host community (Freeman, 1984; Jones and Wicks, 1999; Donaldson and Preston, 1995, Ahmalu et al. 2017). While the signaling theory states that, corporate trustee has obligation to report relevant information to the corporate capital owners, which give help to the operation of business. In the process of reporting, corresponding information is to pass the corporate relevant signal to the capital market. The information can make the operator affect the flow of resources in capital market in a certain extent to improve the enterprise's interests. According, to Kirmani and Rao (2000), for an information to have influence, it should reduce information asymmetry among those involve in the contract and it should be able to describe the information while Erdem and Swait (1998) is of the opinion that a signal should be transparent to both the provider and the user and must be credible to be give adverse effect to the provider of wrong. Therefore, the auditors has a responsibility to protect the interest of the various 
stakeholders by ensuring that, the published financial statement is free of the director's influence and any material misstatement.

\section{Empirical Review}

\section{Effect of Length of Audit Tenure on Earnings Management}

There are two opposing views on the effects of auditor tenure on audit quality. One states that, as the auditor-client relationship lengthens, the auditor develops a close relationship with the client and become more likely to act in favor of management, thus reducing audit quality. This view supports mandatory audit partner rotation. The other view is that, as auditor tenure lengthens, auditors increase their understanding of their clients' business and develop their expertise during the audit, resulting in higher audit quality. The literature on auditor tenure has generally concluded that, long auditor tenure does not impair audit quality. Most of the researches on audit tenure used issuing going concern opinion and bankruptcy as a measure for audit quality.

Chinwe and Chinwuba (2012), on auditors' independence, auditors' tenure and audit firm size in Nigeria concludes that auditor's tenure does not compromise the independence of the auditors and recommended that, the length of audit tenure should not exceed 5 years. Mgbame et al. (2012), on audit partner tenure and audit quality in Nigeria also concluded a significant negative relationship between auditor tenure and audit quality. Nuraddeen and Hasnah (2015) examined the impact of audit committee and audit quality on preventing earnings management in the pre- and post- Nigerian corporate governance code 2011. They concluded that, there is a significant negative relationship between auditor's tenure and discretionary accruals in the pre- and post-code 2011. Also, Ahmed Ebrahim (2011) on auditing quality, auditor tenure, client importance, and earnings management concluded that auditor's tenure is negatively related to the magnitude of discretionary accruals indicating that, auditors become more familiar with clients operations and financial reporting environment, with the time and this enables them to detect and prevent any opportunistic usage of accruals. Adeniyi and Mieseigha (2013) on audit tenure: an assessment of its effects on audit quality in Nigeria concludes a negative relationship between auditor tenure and audit quality, while recommending the financial reporting council and other regulatory bodies in line with best practices to look critically into the issue of auditor tenure and its impact on audit quality in Nigeria.

However, Myers et al. (2003), on exploring term of the auditor-client relationship and the quality of earnings on US companies concludes that earnings management decrease with longer auditor tenure. As longer audit tenure enables auditors to place constraints on extreme management decisions in presenting financial statements. Geiger and Raghunandan (2002), measured audit quality as whether the auditor had issued a going-concern qualification in the prior year for US clients that declared bankruptcy. They concluded that, long association between a client and an audit firm might impair their independence. Ghosh and Mood (2005), investigated auditor tenure and perceptions of audit quality. They also found a positive association between audit tenure and earnings management 
and concluded that, long-served auditors may surrender their independence to keep close relationship with their clients Weerapong et al. (2013), on earnings management and audit quality in southeast Asia reported that long audit tenure impair audit. Cheong, et al. (2015) on audit quality, earnings management, and financial performance of Malaysian public listed companies concluded that audit tenure is insignificantly related to earnings management. While, Walker, et al. (2001) on mandatory auditor's rotation: arguments and current evidence concludes that risk increases early in audit client relationship and then extends over long-term periods, as the failure rate in long-term engagements is low. They further states that auditor rotation might not necessarily improve audit quality. This finding is against the finding of Johnson, Khurana and Reynolds (2002), who concluded that, longer audit tenure weakens audit quality. Davis, et al. (2000), on auditor tenure, auditor independence and earnings management concludes positive effect of auditor tenure on absolute discretionary accruals. Studies such as Carey \& Simnett (2006), supports placing limits on audit partner tenure. Others, such as Chen et al. (2008), and Chi et al. (2009) suggested that longer tenure actually improves audit quality and reduce earnings management. Possibly because it leads to greater knowledge of a client's business.

\section{Effects of Audit Firm Size on Earnings Management}

Becker et al. (1998) supports positive relationship between audit firm size and audit quality in the effect of audit quality on earnings management. As Inaam and Fatma (2012) on audit quality and earnings management in Tunisia found an association between audit quality and earnings management. They reported negative and significant relationship between Big 4 auditors and the earnings management while concluding that firms audited by the big 4 audit companies have less discretionary accrual. Zuo and Guan (2014), on association of audit firm size and industry specialization on earnings management in China concludes that audit firm size is significantly negatively related to earnings management, especially for firms with income-increasing abnormal accruals. They supported the use of the big audit firms. Furthermore, Weerapong et al. (2013) on earnings management and audit quality in Southeast Asia concluded that companies audited by a big firm have less discretionary accruals than those audited by a non-big firm. Finally Krishnan and Schauer (2000), worked on the differentiation of quality among auditors, they concluded that, compliance increases with big six audit firms than non-big six.

However, Alpaslan (2013) on big four auditors, audit quality and earnings management from Turkish stock market concluded that no significant difference between the discretionary accruals of firms audited by big four and non-big four auditors. They reported that no difference in audit quality between big four and non-big four audit firms for restriction of earnings management in Turkey. Jeong and Rho (2004), examine whether big auditors provide higher quality audits than non-Big auditors in Korea, where the institutional setting does not motivate auditors to provide quality audits. They concluded that, there is no difference in audit quality between Big and non-Big auditors in Korea. 
While Naz et al. (2011), on the impact of firm size and capital structure on earnings management in Pakistan reports that size of firm is positively related to earning management which implies that the bigger the audit firm the higher the level of earnings management. Kim et al. (2003) on firm size and earnings management in Hawaii and argued that, size has a positive effect on earnings management.

\section{Effect of Audit Committee Independence on Earnings Management}

Klein (2002), in audit committee board of director's characteristics and earnings management found a negative relationship between audit committee independence and abnormal accrual. He concluded that if audit committee is fully independent, effective earnings management will be curtailed. Sun and Liu (2013) on examining auditor industry specialization, board governance, and earnings management in US found a negative and significant relationship between audit committee independence and earnings management meaning that an independent audit committee reduces management chances of manipulating reported earnings. However, Onalo et al. (2013) in corporate governance and earnings quality focus on some critical but specific features of audit committee including the existence of board or shareholders audit committees, independent non-executive or shareholder audit committee chairman, its frequency of meetings and size. Their result also showed that audit committee independence is negatively related to earnings management. Furthermore, Abdul and Ali (2006) on board, audit committee culture and earnings management in Malaysia concludes insignificant negative relationship between audit committee independence and earnings management while reporting less earnings manipulation where audit committee is independent. Park and Shin (2003) in board composition and earnings management in Canada report significant negative relationship between the audit committee independence and earning management meaning that less earnings management where audit committee independence is high.

However, Fodio et al. (2013), in their study on corporate governance mechanisms and reported earnings quality in Nigeria insurance companies found a positive association between earnings management and audit committee independence. They concluded that, if an executive director is a member of the audit committee, it is likely that, there will be financial statement fraud. Dechow et al. (1996), in causes and consequences of earnings manipulation in US security and exchange commission from 1982-1992. They concluded that, firms with owner of the company, as CEO and member of audit committee are more likely to have financial statement fraud and earnings overstatement. Gulzar and Zongjun in corporate governance characteristics and earnings management of Shanghai and Shenzhen stock exchange found no association between the level of discretionary accruals, earnings management measure, and the presence of an audit committee in a firm. Molik et al. (2013) on earnings management during the Global Financial Crisis in Australian concludes that firms engaged in higher level of incomedecreasing earnings management during the Global Financial Crisis, with the exception of audit committee independence, audit quality, in general, did not have an impact in mitigating this behavior. 
Effect of Financial Literacy of Audit Committee Members on Earnings Management

Carcello et al. (2006) on audit committee financial expertise, competing corporate governance mechanisms, and earnings management in New York concludes that the presence of at least one audit committee member with financial expertise is associated with a lower possibility of destructive earnings management. Dhaliwal et al. (2007), in Audit committee financial expertise, corporate governance and accruals quality, investigated three types of financial experts (accounting, finance, and supervisory), in the audit committee in US stock exchange, and found a positive relation between accruals quality and accounting experts. This implies that audit committee with financial expertise increases the chances of earnings management using accruals while Patrick et al. (2013) in audit committee financial expertise and earnings management found that audit committee financial expertise is negatively related to earnings management. They concludes that audit committees with both financial expertise and high relative status are more effective at deterring earnings management. Marra et al. (2011) on board monitoring and earnings management pre and post-IFRS found that the financial expertise of audit committee members has a negative relationship with earnings management, meaning it's required a high degree of financial sophistication for audit committee member to improve audit committee's effectiveness in monitoring discretionary accruals. According to Song and Windram (2000), in the effectiveness of audit committee in UK they concluded that, a high degree of financial literacy is necessary for an audit committee to perform its duty of financial control and reporting.

\section{Effect of Audit Fees on Earnings Management}

Gul et al. (2003), examined discretionary accounting accruals, manager's incentives, and audit fees in Australian firms. They concluded that, audit fees could increase in the level of unsigned discretionary accruals because of discretionary accruals proxy for managerial opportunism, audit fees provide managers with a means of managing reported earnings to their advantage. Using audit fees as proxy for auditor's independence, Olabisi et al. (2017) in audit quality and earnings management among Nigerian listed deposit money banks between 2005-2014 with a sample size of 15 banks they concluded that auditor independence has a significant positive effect on earnings management as managers deliver honorable fees and engage auditors in non-audit services to increase familiarity and reduce objectivity in the audit process thereby creating room for earnings management.

Healy (1985) on effect of bonus schemes on accounting decision of U.S. industrial corporations concluded that audit fees affects earnings management because accruals are associated with high-risk accounts such as accounts receivable and inventories. While Simon, et al. (2014), on audit partners' economic incentives and accruals-based earnings management reported absolute significant negative discretionary accruals. Meaning that discretionary are higher when the extent of fee-based compensation, measured as the association between partner compensation and generated audit fees is higher. Frankel et al. (2002), on audit 
fees for non-audit services and earnings quality concluded that audit fees are negatively associated with earnings management while non-audit fees are positively associated with small earnings surprises and the magnitude of discretionary accruals, they also reported negative association between non-audit fees and share values on the date the fees were disclosed. Okolie et al. (2013) on audit quality and accrual-based earnings management concluded positive significant association between audit fee and the level of discretionary accruals. This empirically validates the findings of Frankel et al. (2002) that higher fees may result in the impairment of auditor independence and hence create greater opportunities for accrual manipulations. Carol et al. (2006) in prominent audit clients and the relation between discretionary accruals and non-audit service fees concluded that higher proportions of non-audit fees are associated with higher income-increasing accruals. Meaning that higher fees paid to auditors are associated with higher levels of income-decreasing discretionary accruals that leads to more negative discretionary accruals.

Amin et al. (2014) on effect of real earnings management on audit fees found that real earnings management positively influences audit fees through increase in production costs as well as decrease in discretionary expenditures. Furthermore, Nam, Le Hoai (2014) on earnings management and audit fee responses in New Zealand found positive relationship between the absolute level of discretionary accruals in the current year and the level of audit fees paid by an audit client in the next ensuing year. Meaning that auditors might have more incentives to compromise their independence in exchange for a more rewarding level of fees from their client firms. While Steven and Mussie (2016) on the relationship between audit fees and earnings quality reported that bank that pay relatively higher audit fees have lower earnings quality in terms of discretionary accruals also, Caitlin et al. (2014), Non-Audit Services and Earnings Management: Is Auditor Independence Impaired? The study provided additional evidence on the extent to which the purchase of non-audit services from the incumbent auditor is associated with earnings management using ordinary least square regression, time series of audit fees paid and abnormal accrual as proxy for audit fees and earnings management in Australian firms.

They concluded that, audit fees is positively associated with abnormal accruals. Abbott et al. (2006), examined earnings management, litigation risk, and asymmetric audit fee in US, They found a positive relation between incomeincreasing earnings management risk and audit fees. They are of the opinion that, negative discretionary accruals, is associated with lower audit fees while positive discretionary accruals, is associated with higher audit fees. They concluded that, discretionary accruals has a positive effect on audit in the magnitude of income increase accrual, and a negative effect on the magnitude of income decreasing accrual, as a result of asymmetric litigation risk on the auditor.

In summary, Dhaliwal et al. (2007) concluded that there is no effect between financial expertise of audit committee members on earnings management in US using accrual quality model that captures the intentional and unintentional accrual estimation errors by management without considering modified jones and performance matching model. Gul et al. (2003) and Healy (1985) are of the view 
that audit fee increases earning management using jones discretionary accrual while excluding performance matching of earning management. Park and Shin (2003) find out that audit committee independence does not reduce abnormal accrual using modified jones discretionary accrual without taking cognizance of performance matching model in Canada. Studies in Nigeria such as Nuraddeen and Hasnah (2015), Fodio et al. (2013) and others captures discretionary and nondiscretionary accruals using modified jones model. We brought in performance matching model of earning manipulation to draw comparison between the model efficiency and to control organizational performance.

\section{Methodology}

\section{Research Design}

The study was based on ex facto design, using secondary data obtained from financial information comprising of insurance companies in Nigerian stock Exchange from 2012 - 2017 because of the sectors' importance to the economy and the high risk associated with it. We create an unbalanced panel because some institutions are consistent in uploading their published report while some are not consistent.

\section{Model Specification and Measurement of Variables}

In specifying our linear regression model for the effects on earnings management, our major variables are audit tenure (AUDTE), audit firm size (AUDFS), audit committee independence (AUCID), financial literacy of audit committee members (FLACM), audit fees (AUDFE) and also included in the model are cross-section (insurance sector) and years (2012 - 2015). We used modified jones model for earnings management (discretionary accrual as used by Olabisi et al. (2017), Dechow et al. (1996); Guay et al. (1996) and performance matching model as used by Kothari, et al. (2005) and Aulia et al. (2013). The panel multiple regression with an error term $(\mu \mathrm{i})$ is expressed in the following equation:

$\mathrm{EM}_{\mathrm{it}}=\alpha_{\mathrm{it}}+\beta_{1}$ AUDTE $_{\mathrm{it}}+\beta_{2}$ AUDFS $_{\mathrm{it}}+\beta_{3} \mathrm{AUCID}_{\mathrm{it}}+\beta_{4} \mathrm{FLAGM}_{\mathrm{it}}+\beta_{5} \mathrm{AUDFE}_{\mathrm{it}}+\mu_{\mathrm{it}}$

We also used the following models to test our dependent variable.

\section{Model 1: Audit Quality vs. Discretionary Accrual (First Dependent Variable)}

To ascertain earnings management, the model uses a two-stage approach to apportion total accrual into discretionary and non-discretionary accrual. The first stage helps to control non-discretionary accrual as a result of depreciation charged and changes in economic activity while the second stage helps to determine discretionary accrual by deducting changes in debtors from changes in revenue. Therefore, it assumes that all changes in receivables in the event period might be 
as a result of earnings management and therefore takes cognizance of accounts receivables. Thus, to estimate these variables, the following formula as used by Francis et al. (2005) adapted by Fodio et al. (2013) Okolie et al. (2013) in Nigeria applies

$\mathrm{DAC}_{\mathrm{it}}=\left\{\mathrm{TA}_{\mathrm{it}}\right\}-\left[\left(\beta \mathrm{o}(1 / \mathrm{At}-1)_{\mathrm{it}}+\beta \mathrm{i}(\Delta \mathrm{REVt}-\Delta \mathrm{RECt})_{\mathrm{it}}+\beta \mathrm{ii}(\mathrm{PPEt}]_{\mathrm{it}}\right.\right.$

$\mathrm{TA}_{\mathrm{it}}=$ total accruals of insurance is calculated as the difference between profit or loss before taxation, and operating cash flows for year $t$; $1 /$ At- $1=$ assets at the beginning of the year, $\Delta \mathrm{REC}=$ the change in receivables from year $\mathrm{t}-1$ to $\mathrm{t} \Delta \mathrm{REV}$ $=$ changes in gross earnings from $\mathrm{t}-1$ to $\mathrm{t}$. The panel regression with an error term $(\mu \mathrm{i})$ for model 1 is expressed in equation (1)

DAC $_{\text {it }}=\mathrm{f}($ AUDTE + AUDFS + AUCID + FLACM + AUDFE $)$

DAC $_{\text {it }}=\alpha i+\beta^{1}$ AUDTEit $+\beta^{2}$ AUDFSit $+\beta^{3}$ AUCIDit $+\beta^{4}$ FLAGMit $+\beta^{5}$ AUDFEit + $\mu \mathrm{i}$

\section{Audit Quality vs. Performance Matching (Second Dependent Variable)}

We used performance matching model to test our second dependent variable, developed by Kothari et al. (2005). The performance matching model draw comparison between the model efficiency in contrast with the regression-based approach specifically the original and the modified Jones model. The major aim of this model is to address the issue of relationship between performance and accrual in the modified jones model, it utilizes residuals from the annual cross-sectional industry regression because it comprises return on assets, which is used to control organizational performance and a constant, which provides a greater degree of control in terms of heteroskedasticity, The model is seen as:

$$
\begin{aligned}
& \text { TAit }=\beta^{0}+\beta^{1}\left(\frac{1}{\text { Ait }}-1\right)+\beta^{2}(\triangle R E V t-\triangle R E C t)+\beta^{3} P P E i t+\beta^{4} R O A i t+\epsilon_{\mathrm{i}} \\
& \text { PMit }=\mathrm{f}(\text { AUDTE }+ \text { AUDFS }+ \text { AUCID }+ \text { FLACM + AUDFE }) \\
& \mathrm{PM}_{\mathrm{it}}=\alpha_{\mathrm{it}}+\beta_{1} \mathrm{AUDTE}_{\mathrm{it}}+\beta_{2} \text { AUDFS }_{\mathrm{it}}+\beta_{3} \text { AUCID }_{\mathrm{it}}+\beta_{4} \mathrm{FLAGM}_{\mathrm{it}}+\beta_{5} \mathrm{AUDFE}_{\mathrm{it}}+\mu_{\mathrm{it}}
\end{aligned}
$$

where

$\mathrm{ROA}_{\mathrm{it}}=$ return on assets

Independent variables

AUDTE= length of audit tenure following Adeniyi \& Meiseigha (2013), who measure number of years spent as firms auditor if greater than 3 we assign 1 if otherwise we assign 0 . The apriori sign is $\beta_{1}<0$.

AUDFS=Audit firm size as measured by Krishnan and Schauer (2000), as we assign 1 if financial statement is audited by any of the Big 4 and 0 if otherwise. The apriori sign is $\beta_{2}>0$.

AUCID= Audit committee independence following Onalo et al. (2013), we assign 1 if an independent non-executive is the chairman of the committee and 0 if otherwise. The apriori sign is $\beta_{3}<0$. 
FLACM= Financial literacy of audit committee members as measured by Song and Windram (2000), assign 1 if a financial expert is a member of the audit committee and 0 if otherwise. The apriori sign is $\beta_{4}>0$.

AUDFE $=$ Audit fees measured by Cheong et al. (2015) as Natural log of audit fees paid to an audit firm in a year. The apriori sign is $\beta_{5}<0$.

\section{Data Presentation and Analysis}

To ensure adequate observation for statistical testing, we adopted a panel data analysis to identify the possible effects on earnings management. We conducted descriptive statistics and correlation matrix. Pooled and panel regression with fixed and random effect panel data regression and the Hausman test were also conducted to select between fixed and random effect models.

\section{Data Description and Analysis}

Table 1, shows the mean (average) for each of the variable, the minimum and maximum values and their standard deviation (degree of dispersion) and JarqueBera (JB) statistics (normality test). The results provided some insight into the nature of the selected insurance companies that was used in the study. Firstly, Audit fees, proxy as fees paid to the auditors for the audit assignment, stood at a maximum of N680m and a minimum of N14m. Secondly, the financial literacy of audit committee members stood at the average of 0.78 and the maximum of 1.00 while its minimum is 1.00 meaning that all insurance firms have financial literate members' insider audit committee. Finally, the Jarque Bera (JB) that test the normality or existence of outliers shows that, the values are normally distributed at $1 \%$ level of significance. Therefore, the overall descriptive statistics revealed that, there are no sample selection bias or outlier in the data that, would impair the generalization from this study.

Table 1. Descriptive Statistics

\begin{tabular}{|c|c|c|c|c|c|c|c|}
\hline \multicolumn{7}{|c|}{ Descriptive Statistics } & \\
\hline & AUDTE & AUDFS & AUCID & FLACM & AUDFE & $\begin{array}{c}\text { MODIFIED } \\
\text { JONES }\end{array}$ & PERFORM \\
\hline Mean & 0.31 & 0.63 & 0.68 & 0.78 & 172630 & 25771676 & -1.11 \\
\hline Minimum & 0.00 & 1.00 & 1.00 & 1.00 & 14000 & -2.90 & -618002.0 \\
\hline Maximum & 1.00 & 1.00 & 1.00 & 1.00 & 680000 & 7.70 & 3.23 \\
\hline Std. Dev. & 0.46 & 0.48 & 0.46 & 0.41 & 874431 & 1.18 & 4.65 \\
\hline Jarque-Bera & 27.94 & 25.68 & 27.52 & 46.82 & 15423 & 3250.08 & 5205.60 \\
\hline Probability & 0.00 & 0.00 & 0.00 & 0.00 & 0.00 & 0.00 & 0.00 \\
\hline Observations & 151 & 151 & 151 & 151 & 151 & 151 & 151 \\
\hline
\end{tabular}

Source: Author (2019).

Correlation Analysis

In examining the relationship among the variables, we employed the correlation coefficients (correlation matrix) and the result is presented in Table 2. 
Table 2. Correlation Matrix

\begin{tabular}{|l|c|c|c|c|c|}
\hline & AUDTE & AUDFS & AUCID & FLACM & AUDFE \\
\hline AUDTE & 1.00 & & & & \\
\hline AUDFS & -0.10 & 1.00 & & & \\
\hline AUCID & 0.06 & 0.10 & 1.00 & & \\
\hline FLACM & 0.01 & 0.12 & 0.19 & 1.00 & \\
\hline AUDFE & 0.13 & 0.07 & 0.10 & -0.04 & 1.00 \\
\hline
\end{tabular}

Source: Author (2019).

Table 3 Variance Inflation Factors

\begin{tabular}{|l|c|c|}
\hline Variable & VIF & 1/VIF \\
\hline AUDFS & 1.07 & 0.936657 \\
\hline AUDFE & 1.06 & 0.942352 \\
\hline FLACM & 1.06 & 0.947567 \\
\hline AUDTE & 1.05 & 0.955732 \\
\hline AUCID & 1.04 & 0.963659 \\
\hline Mean VIF & $\mathbf{1 . 0 5}$ & \\
\hline
\end{tabular}

Source: Author (2019).

In Table 2, we focus on the correlation between the five independent variables. The result shows that audit tenure (AUDTE) was weakly negatively related to audit firm size (-0.10), it implies that audit firm size does not determine the number of years the auditor spent with each audit client. In the case of audit committee independence (AUCID AUDTE=0.06, AUDFS=0.10), we observed audit committee independence was positive and weakly related to audit tenure at 0.06 and audit firm size at 0.10 , meaning that audit tenure is determined by the presence of independent audit committee and audit firm size. Thirdly, this (FLACM AUDTE=-0.01 AUDFS 0.12 and AUCID 0.19) indicates financial literacy of audit committee member is weakly positively related to audit tenure at 0.01 and strongly positively related to audit firm size and audit committee independence at 0.12 and 0.19 respectively. In table 3 we Checked for multicolinearity with the use of the variance inflation factor, we notice that no two explanatory variables were perfectly correlated, as the VIF mean was 1.05 , which is much lower than the threshold of 10. This means that there is the absence of multicolinearity problem in our model. Multicollinearity between the explanatory variables may result wrong signs or implausible magnitudes, in the estimated model coefficients, and the bias of the standard errors of the coefficients.

\section{Regression Results}

However, to examine the impact between the dependent variables earnings management and audit quality and to also test our formulated hypotheses, we used a panel data regression analysis since the data had both time series (2012 to 2015) and cross-sectional properties (insurance companies). The panel data regression results are presented and discussed below (Table 4).

In testing for the cause-effect between the dependent and independent variables in earnings management (modified jones), we reported pooled and panel analysis. The study adopted pooled and panel data regression models (fixed effect and panel data estimation techniques). The difference in these models are based on 
the assumptions made about the explanatory variables and cross sectional error term. Since the results would be more appealing statistically in the context of differences in our sampled companies.

In table 3, we presented an OLS pooled regression and three panel data estimation techniques (ordinary least square, fixed effect and random effect). The three results revealed difference in their coefficients magnitude, signs and number of significant variables. This clearly shows that, pooled OLS regression does not reflect the heterogeneity in the sampled financial institutions. This effect is reflected in the two panel data regression results. In selecting from the two panel data models, the Hausman test was conducted and the result shows that, we should accept H0 (adopt fixed effect model and reject random effect model). This means that, we will adopt, interpret and draw conclusion as well as recommendation from the fixed effect panel data regression results.

Table 4 Panel Regression Result Modified Jones Model

\begin{tabular}{|c|c|c|c|c|}
\hline & $\begin{array}{l}\text { Aprior } \\
\text { Sign }\end{array}$ & $\begin{array}{c}\text { ModiJonesModel } \\
\text { (OLS Pooled) }\end{array}$ & $\begin{array}{c}\text { ModiJonesModel } \\
\text { (Fixed Effect }\end{array}$ & $\begin{array}{l}\text { ModiJonesModel } \\
\text { (Random Effect) }\end{array}$ \\
\hline \multirow[t]{3}{*}{$\mathrm{C}$} & & -3.6 & -0.9 & -1.52 \\
\hline & & $(-1.4)$ & $(-0.0)$ & $(-0.56)$ \\
\hline & & {$[0.1]^{*}$} & {$[0.9]^{*}$} & {$[0.5]^{*}$} \\
\hline \multirow[t]{3}{*}{ AUDTE } & - & -1.6 & -1.98 & -1.15 \\
\hline & & $(-0.7)$ & $(0.14)$ & $(-0.0)$ \\
\hline & & {$[0.04]^{* * *}$} & {$[0.08]^{*}$} & {$[0.09]^{*}$} \\
\hline \multirow[t]{3}{*}{ AUDFS } & + & 4.5 & -4512 & 1.86 \\
\hline & & $(2.2)$ & $(0.0)$ & $(0.0)$ \\
\hline & & {$[0.1]^{*}$} & {$[0.09]^{*}$} & {$[0.4]^{*}$} \\
\hline \multirow[t]{3}{*}{ AUCID } & + & -2.2 & 9035 & -2.71 \\
\hline & & $(-1.0)$ & $(0.0)$ & $(-0.1)$ \\
\hline & & {$[0.2]^{*}$} & {$[0.01]^{* * *}$} & {$[0.08]^{*}$} \\
\hline \multirow[t]{3}{*}{ FLACM } & + & 3.6 & 637 & 7.32 \\
\hline & & $(1.5)$ & $(0.0)$ & $(0.4)$ \\
\hline & & {$[0.1]^{*}$} & {$[0.9]^{*}$} & {$[0.6]^{*}$} \\
\hline \multirow[t]{3}{*}{ AUDFE } & - & 268.92 & 140 & 32.5 \\
\hline & & $(0.2)$ & $(0.1)$ & $(0.0)$ \\
\hline & & {$[0.8]^{*}$} & {$[0.0]^{* * *}$} & {$[0.9]^{*}$} \\
\hline R-Squared & & 0.06 & 0.77 & 0.0 \\
\hline Adj-R-Squared & & 0.02 & 0.68 & -0.2 \\
\hline F-Statistic & & $1.89(0.0)^{* * *}$ & $8.66(0.0) * * *$ & $0.17(0.9)^{*}$ \\
\hline Hausman Test & & & & $3.93(0.02)$ \\
\hline \multicolumn{5}{|l|}{ J Statistic } \\
\hline $\mathrm{N}(\mathrm{n})$ & & 151(38) & 151(38) & $151(35)$ \\
\hline
\end{tabular}

Source: Author 2019.

Note: (1) Parentheses ( ) are t-statistic while bracket [ ] are p-values

(2) $* * * 1 \%, * * 5 \%$ and $* 10 \%$ level of significance

Following the above, in Table 4, the R-squared and adjusted R-squared values were $(0.77)$ and (0.68). This implies that all independent variables jointly explain about $77 \%$ of the systematic variations in earnings management (modified jones) of our sampled financial institutions over the four-year period (2012-2015). The above average R-squared value is realistic as it clearly shows earnings 
management and its interaction with audit quality (modified jones). The Fstatistics (8.66) and its p-value (0.0) show that, the earnings management (modified jones) fixed effect regression model is generally significant and well specified. The F-statistic also shows that, the overall earnings management (modified jones) fixed effect regression model is significant at $1 \%$ levels.

In addition to the above, the specific finding from each explanatory variable from fixed effect regression model is provided as follows:

Length of audit tenure: Based on the coefficient of 1.98 and p-value 0.08 , it appears to have a positive influence on our sampled listed financial institutions, earning management (Modified Jones) and was statistically significant at $10 \%$ since it $\mathrm{p}$-value was greater than 0.05 . This result therefore, suggest that, we should reject hypothesis one $\left(\mathrm{HO}_{1}\right)$, which states that, length of audit tenure does not significantly affects earnings management This means that higher length of audit tenure of financial institutions will result to an increase in earnings management . This result does not conform to apriori expectation and it is similar to the findings of Ahmed Ebrahim (2011) Geiger and Raghunandan (2002), who concluded a positive effect that, audit tenure affects earnings management and long audit tenure impair auditor's independence. Ghosh and Mood (2005), who found a positive effect of audit tenure and earnings management and concluded that, long-served auditors may surrender their independence to keep close relationship with their clients. However, in disagreement with Adeniyi and Mieseigha (2013), Mgbame et al. (2012); Olabisi et al. (2017), Okolie et al. (2013) in Nigeria who concludes negative relationship between auditor tenure and audit quality, and in agreement with Chinwe and Chinwuba (2012).

Audit firm size: Based on the coefficient of -4512 and p-value 0.9 , it appears to have a negative effect on our sampled financial institutions. It was also statistically insignificant since it p-value was greater than $10 \%$. This result therefore, suggests that, we should accept hypothesis two $\left(\mathrm{HO}_{2}\right)$, which states that, audit firm size affects earning management. This means that, earnings management is not determined by the size of audit firm. This finding does not conform to apriori expectation. This finding, like similar studies of Nuraddeen and Hasnah (2015); Fodio et al. (2013); Okolie et al. (2013) in Nigeria. Inaam et al. (2012), Zuo and Guan (2014) who concluded a negative effect of audit firm size on earnings management.

Audit committee independence: Based on the coefficient of 9035 and pvalue 0.01 , it appears to have a positive influence on our sampled listed financial institutions, earnings management (Modified Jones), and was statistically significant at $1 \%$ since it $\mathrm{p}$-value was 0.01 . This suggests that we should reject hypothesis three $\left(\mathrm{HO}_{3}\right)$, which states that audit committee independence does not significantly affects earnings management. It means that increase in audit committee independence of financial institutions increases earnings management. The finding also conforms to apriori expectation with similar findings Fodio et al. (2013) and Olabisi et 
al. (2017) in Nigeria; Dechow (1996) who concluded that, if an executive director is a member of the audit committee it's likely to increase earning management therefore if a non-executive director is the chairman of the audit committee earnings management will increase.

- Financial literacy of audit committee members: Based on the coefficient of 637 and p-value 0.9, it appears to have a positive influence on our sampled listed financial institutions, financial literacy of audit committee member was also statistically insignificant since it $\mathrm{p}$-value is greater than $10 \%$. This result suggested we should accept hypothesis four $\left(\mathrm{HO}_{4}\right)$, which states that, there is no significant effect of financial literacy of committee members on earnings management. This means that increase in financial literacy of audit committee members will increase earnings management. The finding also conforms to apriori expectation and similar findings like that, of Carcello et al. (2006), who concluded that, one audit committee member with financial expertise is associated with a lower possibility of destructive earnings management. Patrick et al (2013), found audit committee financial expertise is positively related to earnings management while, Dhaliwal et al (2007), found a positive relation between accruals quality and accounting expert.

Audit fees: Based on the coefficient of 140 and p-value 0.0, it appears to have a positive influence on our sampled listed financial institutions, audit fees was statistically significant at $1 \%$ since it p-value is less than $5 \%$. This result suggests that we should reject hypothesis five $\left(\mathrm{H}_{5}\right)$, which states that, audit fees does not significantly affects earnings management. This means that, fees paid to the auditors by financial institutions goes long way in affecting the opinion given by the auditor by thereby increasing earnings manipulation. This does not conform to apriori expectation. It similar findings like that of Nam, Le Hoai (2014) that concluded positive relationship between the absolute level of discretionary accruals in the current year and the level of audit fees paid by an audit client in the next ensuing year. Gul, et al. (2003), who concluded that, audit fees could increase the level of unsigned discretionary accruals. Healy (1985) concluded that, audit fees affects earnings management positively because accruals are associated with high-risk accounts such as accounts receivable and inventories. Caitlin et al. (2014), concluded that, audit fees is positively associated with abnormal accruals. Abbott et al. (2006), concluded that discretionary accruals has a positive effect on audit in the magnitude of income increases accrual and a negative effect on the magnitude of income decreasing accrual as a result of asymmetric litigation risk on the auditor. The result is in disagreement with Okolie et al. (2013) in Nigeria. 
Table 5. Panel Regression Result Performance Model

\begin{tabular}{|c|c|c|c|c|}
\hline & $\begin{array}{l}\text { Aprior } \\
\text { Sign }\end{array}$ & $\begin{array}{l}\text { ModiJonesModel } \\
\text { (OLS Pooled) }\end{array}$ & $\begin{array}{l}\text { ModiJonesModel } \\
\text { (Fixed Effect) }\end{array}$ & $\begin{array}{l}\text { ModiJonesModel } \\
\text { (Random Effect) }\end{array}$ \\
\hline \multirow[t]{3}{*}{$\mathrm{C}$} & & -1.79 & -1.79 & -2.8 \\
\hline & & $(0.45)$ & $(-0.15)$ & $(-2.5)$ \\
\hline & & {$[0.6]^{*}$} & {$[0.8]^{*}$} & {$[0.7]^{*}$} \\
\hline \multirow[t]{3}{*}{ AUDTE } & - & -3.81 & 2.32 & 1.18 \\
\hline & & $(-0.45)$ & $(-0.36)$ & $(0.19)$ \\
\hline & & {$[0.6]^{*}$} & {$[0.7]^{*}$} & {$[0.8]^{*}$} \\
\hline \multirow[t]{3}{*}{ AUDFS } & + & -3.98 & -229 & -9608 \\
\hline & & $(-0.45)$ & $(-0.01)$ & $(-0.0)$ \\
\hline & & {$[0.6]^{*}$} & {$[0.9]^{*}$} & {$[0.9]^{*}$} \\
\hline \multirow[t]{3}{*}{ AUCID } & - & 1.62 & 689 & 4.77 \\
\hline & & $(1.91)$ & $(0.08)$ & $(0.64)$ \\
\hline & & {$[0.0]^{* * *}$} & {$[0.1]^{*}$} & {$[0.5]^{*}$} \\
\hline \multirow[t]{3}{*}{ FLACM } & + & -4.34 & -568 & -1.51 \\
\hline & & $(0 . .4)$ & $(0.06)$ & $(0.18)$ \\
\hline & & {$[0.6]^{*}$} & $0.9]^{*}$ & {$[0.8]^{*}$} \\
\hline \multirow[t]{3}{*}{ AUDFE } & - & -236 & 60.50 & -44.89 \\
\hline & & $(-0.5)$ & 0.09 & -0.08 \\
\hline & & {$[0.5]^{*}$} & {$[0.0]^{* * *}$} & {$[0.9]^{*}$} \\
\hline R-Squared & & 0.02 & 0.67 & 0.00 \\
\hline Adj-R-Squared & & -0.001 & 0.54 & -0.03 \\
\hline F-Statistic & & $0.79(0.5)^{*}$ & $5.36(0.00) * * *$ & $0.09(0.9)^{*}$ \\
\hline Hausman Test & & & & $3.19(0.06)^{*}$ \\
\hline \multicolumn{5}{|l|}{ J Statistic } \\
\hline $\mathrm{N}(\mathrm{n})$ & & 151(38) & 151(38) & $208(26)$ \\
\hline
\end{tabular}

Source: Author 2019 Note: (1) Parentheses ( ) are t-statistic while bracket [ ] are p-values (2) *** $1 \%, * * 5 \%$ and $* 10 \%$ level of significance.

In table 5, we presented an OLS pooled regression and two panel data estimation techniques (fixed effect and panel data estimator). The three results revealed difference in their coefficients magnitude, signs and number of significant variables. This clearly shows that, pooled OLS regression does not reflect the heterogeneity in the sampled companies. This effect is reflected in the two panel data regression results. In selecting from the two panel data models, the Hausman test was conducted and the result shows that, we should accept $\mathrm{HO}$ (adopt fixed effect model and reject random effect model). This means that, we adopt and interpret fixed effect panel data regression results. The R-squared and adjusted R-squared values were (0.67) and (0.54). This indicates that, all independent variables jointly explain about $67 \%$ of the systematic variations in earnings management of our sampled companies. The above average R-squared value is realistic as it clearly shows earnings management and its interaction with audit quality. The F-statistics (5.36) and its p-value (0.0) show that, the earning management fixed effect regression model is generally significant and well specified. The F-statistic also shows that, the overall earnings management fixed effect regression model is significant at $1 \%$ levels.

In addition to the above, the specific finding from each explanatory variable from fixed effect regression model is provided as follows: 
Length of audit firm tenure: Based on the coefficient of 2.32 and p-value 0.07 , it appears to have a positive influence on our sampled listed financial institutions, earning management (performance matching model) and was statistically significant at $10 \%$ since it p-value was less than 0.10 . This result suggests that we should reject hypothesis one $\left(\mathrm{H}_{1}\right)$, which states that length of audit tenure does not significantly affects earnings management. It means that increase in the length of audit tenure on financial institutions increases earnings management. This result was in agreement with Ahmed Ebrahim (2011) and Geiger and Raghunandan (2002), Chinwe and Chinwuba (2012), Mgbame et al. (2012) in Nigeria, while in disagreement with Adeniyi and Mieseigha (2013), Olabisi et al. (2017), Okolie et al. (2013) in Nigeria.

Audit firm size: Based on the coefficient of -229 and p-value 0.9, it appears to have a negative effect on our sampled financial institutions. It was statistically insignificant since it p-value was greater than $10 \%$. This result suggests that we should accept hypothesis two $\left(\mathrm{HO}_{2}\right)$, which states that audit firm size does not significantly affects earning management. Meaning that increase in the use of the big 4 audit firms will reduce earnings management. We accept the findings of Weerapong et al. (2013) on earnings management and audit quality in Southeast Asia that concludes, companies audited by a big firm have less discretionary accruals than those audited by a non-big firms. It is in agreement with Fodio et al. (2013); Okolie et al. (2013); Nuraddeen and Hasnah (2015) in Nigeria. Inaam et al. (2012), Zuo and Guan (2014).

Audit committee independence: Based on the coefficient of 689 and pvalue 0.01 , it appears to have a positive influence on our sampled listed financial institutions, earnings management (performance matching) and was statistically significant at $1 \%$ since it $\mathrm{p}$-value was 0.01 . This result suggests that we should reject hypothesis one $\left(\mathrm{HO}_{3}\right)$, which states that audit committee independence does not significantly affects earnings management. It means that increase in audit committee independence will increase earnings management. It is in agreement with Fodio et al. (2013) and Olabisi et al. (2017) in Nigeria; Dechow (1996)

Financial literacy of audit committee members: Based on the coefficient of -568 and p-value 0.9 appears to have a negative influence on our sampled listed financial institutions, financial literacy of audit committee member was also statistically insignificant, since it $\mathrm{p}$-value is greater than $10 \%$. This result suggests that we should accept hypothesis four $\left(\mathrm{HO}_{4}\right)$, which states that financial literacy of committee members does not significantly affects earnings management. Meaning that increase on members of audit committee that have accounting background will reduce earnings management. It is in disagreement with Carcello et al. (2006); Patrick et al. (2013); Dhaliwal et al. (2007).

Audit fees: Based on the coefficient of 60.58 and p-value 0.0, it appears to have a positive influence on our sampled listed financial institutions, audit fees was also statistically significant at $1 \%$ since it $p$-value is less than $5 \%$. 
This result suggests that we should reject hypothesis five $\left(\mathrm{HO}_{5}\right)$, which states that audit fees does not significantly affects earnings management. This means that increase in audit fees will increase earnings management. The result is in disagreement with Okolie et al. (2013) in Nigeria. It is in agreement with Nam, Le Hoai (2014); Gul et al. (2003); Healy (1985); Caitlin et al. (2014); Abbott et al. (2006).

\section{Conclusion and Recommendation}

The result indicates a significant positive effect of audit quality on earnings management. We concluded that the longer the auditor's stay in financial institutions leads to increase in client familiarity, which creates room for accrual and performance earning management. Financial institutions audited by big four auditing firms reduces accrual and performance earnings manipulation. Financial institutions that are having executive and non-executive directors as members of audit committee leads to increase in accrual and performance earnings manipulations. However, higher number of financial experts in audit committee leads to accrual manipulation of earnings while higher number of experts with accounting background in audit committee leads to reduction in performance manipulating of earnings. As the auditors' fee goes up, it influences the auditing firms by making financial institutions manipulate earnings by taking advantage of the flexibility in the choice of accounting methods of both accrual and performance earnings manipulation. Therefore, the study recommends that, financial institutions should have maximum number of years for auditors' stay. They should focus more on increasing the number of experts with accounting background in audit committee. Accounting bodies should regulate auditors' fee in line with the size of the financial institution.

\section{References}

Abbott, L.J., Parker, S., \& Peters, G.F. (2006). Earnings management, litigation risk, and asymmetric audit fee responses. A journal of practice \& theory: 25(1), 85-98. https:// doi.org/10.2308/aud.2006.25.1.85.

Abdul, R.A. (2006). Board, audit committee, culture and earnings management: Malaysian Evidence. Managerial Auditing Journal 21(7), 783-804.

Adeniyi, S., \& Mieseigha, G. (2013). Audit Tenure: an Assessment of its Effects on audit quality in Nigeria. International journal of academic research in accounting, finance and management sciences. 3(3), 275-283.

Adeyemi, S., Okpala, O., \& Dabor, E. (2012). Factors affecting audit quality in Nigeria International Journal of Business and Social Science 3(20), 198-209.

Ahmed, E. (2011). Auditing Quality, Auditor Tenure, Client Importance, and Earnings Management: An Additional Evidence Unpublished, Rutgers University.

Akerlof, G. (1970). The market of 'lemons': Quality uncertainty and the market mechanism. The Quarterly Journal of Economics, 84(3), 488-500. 
Aliyu, M.D., Musa, A.U., \& Zachariah, P. (2015). Impact of audit quality on earnings management of listed deposit money banks in Nigeria Journal of Accounting and Finance Management 1(4), 1-16.

Alpaslan, Y. (2013). Big Four Auditors'Audit Quality and Earnings Management: Evidence from Turkish Stock Market International Journal of Business and Social Science. 4(17), 153-163.

Ahmalu, N., Moses, N., \& Obi, C. (2017). Audit quality determinants Evidence from quoted Health care firms in Nigeria International journal of Academic Research in Accounting Finance and Management Science 7(4), 216-236.

Aulia, F., Mohamat, S., Norman, M., \& Zaleha, A. (2013). The effect of underinvestment on the relationship between earnings management and information asymmetry AAMJAF 9(2), 1-28.

Amat, O., Oscar, E., \& Petya, P. (2014). Earnings management and audit adjustments: An Empirical study of Ibex 35 constituent https://dx.doi.org/10.2139/ssrn.1374232.

Amin, G., Haleh, A., \& Mehran, M. (2014). The effect of real earnings management on audit fees in listed companies in Tehran Stock Exchange Management Science Letters (4), 2251-2260.

Aziatul, W., Nur, A., \& Zuraidah, M. (2015). Earnings Management: An Analysis of Opportunistic Behavior, Monitoring Mechanism and Financial Distress Procedia Economics and Finance (28), 190-201.

Barbadillo, E., Aguilar, N., \& Carrera, N. (2009). Does auditor tenure improve audit quality. "Mandatory auditor rotation versus long term auditing: An empirical analysis". Working paper, University of Cadiz, Spain. Auditing a Journal of Practice \& Theory 28(1) DOI: 10.2308/aud.2009.28.1.113.

Becker, C., DeFond, M., Jiambalvo, J., \& Subramanyam, K. (1998). The effect of audit quality on earnings management. Contemporary Accounting Research 15(1), 1-24.

Caitlin, R., Kate, S., \& Stephen, T. (2014). Non-Audit Services and Earnings Management: Is Auditor Independence Impaired? Contemporary Accounting Research 23(3), 701746.

Carcello, J.V., Hollingsworth, C.W., Klein, A., \& Neal, T.L. (2006). Audit committee financial expertise, competing corporate governance mechanisms, and earnings management. Retrieved from http://ssrn.com/abstract=887512.

Carey, P., \& Simnett, R. (2006). "Audit Partner Tenure and Audit Quality, The Accounting Review 81(3), 653-676.

Carol, C.D., Ayalew, L., \& Tanya, S.N. (2006). Prominent Audit Clients and the Relation between Discretionary Accruals and Non-Audit Service Fees Advances in accounting $22,123-148$

Chen, C., Lin, C., \& Lin, Y. (2008). Audit partner tenure, audit firm tenure, and discretionary accruals: Does long auditor tenure impair earnings quality? Contemporary Accounting Research, 25(2):415-445.

Cheong, P., Boon, H., Ong, T.C., \& Hong, Y. (2015). The Relationship among Audit Quality, Earnings Management, and Financial Performance of Malaysian Public Listed Companies Journal of Economics and Management 9(1), 211-229.

Chi, W., Huang, H., Liao, Y., \& Xie, H, (2009). Mandatory audit partner rotation, audit quality, and market perception: Evidence from Taiwan. Contemporary Accounting Research, 26(1), 359-391.

Chinwe, C., \& Chinwuba, O. (2012). Auditors Independence, Auditors' Tenure and Audit Firm Size in Nigeria Research journal of finance and accounting 3(10),137-143 ISSN 2222-1697 (Paper) ISSN 2222-2847 (Online). 
Davis, R., Soo, B., \& Trompeter, G. (2000). Auditor tenure, Auditor Independence and Earnings Management; Working Paper, Boston College, Boston, https://www2.aaa hq.org/audit/midyear/01midyear/papers/soo.pdf.

DeAngelo, L. (1981) Auditor size and audit quality. Journal of Accounting and Economics 3(2), 183-199.

Dechow, P.M., Sloan, R.G. \& Sweeney, A.P. (1996) Causes and consequences of earnings manipulation: An analysis of firms subject to enforcement actions by the SEC. Contemporary Accounting Review 13(1), 1-36.

Dhaliwal, D., Naiker, V., \& Zealand, N. et al. (2007). Audit committee financial expertise, corporate governance and accruals quality an empirical analysis audit committee financial Expertise, Corporate Governance and Accruals Quality: DOI 102139/ssrn. 906690.

Donaldson, T. \& Preston, I. (1995). Stakeholder theory of the corporation: Concepts, evidence, implications. Acad. Manage. Rev.20, 65-91.

Erdem, T., \& Swait, J. (1998). Brand equity as a signaling phenomenon. Journal of Consumer psychology, 7(2), 131-157.

Francis, J., Olsson, P., Lafond, R. et al. (2005). The Market Pricing of Accrual Quality journal of Accounting and Economics 39(2), 295-327.

Frankel, R.M., Johnson, M.F. \& Nelson, K.K. (2002). The relationship between audit fees for non-audit services and earnings quality. The Accounting Review 77 (Supplement), 71-105. Advances in Accounting Volume 22, 2006, 123-148.

Freeman, R.E. (1984). Strategic management: A stakeholder approach. Boston, Pitman. DOI: $10.2139 / \mathrm{ssrn} .263511$.

Fodio, M.I., Ibikunle, J. \& Oba, V.C. (2013). Corporate governance mechanisms and reported earnings quality in listed Nigerian insurance firms. International Journal of Finance and Accounting, 2(5), 279-286. DOI: 10.5923/j.ijfa.20130205.01.

Geiger, M.A. \& Raghunandan, K. (2002). "Auditor tenure and audit reporting failures, Auditing, 21(1), 67-78.

Ghosh, A. \& Moon, D. (2005). Auditor tenure and perceptions of audit quality. The Accounting Review, 80(2), 585-612.

Guay, W., Kothari, S.P., Watts, R. (1996). A Market-Based Evaluation of Discretionary Accrual Models. Journal of Accounting Research, 34(Supplement), 83-105.

Gul, F., Chen, C., \& Tsui, J. (2003). Discretionary accounting accruals manager's incentive and audit fees contemporary accounting research 20(3), 441-464.

Gulzar, A. \& Zongjun, W. (2011). Corporate Governance Characteristics and Earnings Management: Empirical Evidence from Chinese Listed Firms International Journal of Accounting and Financial Reporting 1(1) ISSN 2162-3082 DOI:10.5296/ijafr.v1 i1.854.

Healy, P.M. (1985). The Effect of Bonus Scheme on Accounting Decision. Journal of Accounting and Economics. 7(1), 85-107.

Healy, P.M. \& Wahlen, J.M. (1999). A Review of the Earnings Management Literature and its Implications for Standard Setting. Accounting Horizon, 13(4), 365-383.

Hepworth, S.R. (1953). 'Smoothing periodic income.' The Accounting Review, vol. 28(1), 32-39.

Inaam, Z. \& Fatma, Z. (2012). Audit quality and earnings management in Tunisian context International journal of accounting and financial reporting 2(2).

Jeong, S.W. \& Rho, J. (2004). Big Six Auditors and Audit Quality: The Korean Evidence. The International Journal of Accounting. Vol: 39, 175-196.

Jiraporn, P., Gary, A.M., Yoon, S.S. et al. (2008). Is earnings management opportunistic or beneficial? An agency theory perspective. International Review of financial analysis (17), 622-634. 
Johnson, V.E., Khurana, I.K. \& Reynolds, J.K. (2002). Audit-firm tenure and the quality of financial reports. Contemporary Accounting Research 19(4), 637-660.

Jones, T.M. \& Wicks, A.C. (1999). Convergent stakeholder theory. Acad. Manage. Rev. 24(2), 206-221.

Kim, Y, Liu, C. \& Rhee, G. (2003).The Effect of Firm Size on Earnings Management. Working http://citeseerx.ist.psu.edu/viewdoc/download? doi=10.1.1.518.3838\&rep=re p1\&type $=$

Kirmani, A. \& Rao A.R. (2000). No pain, no gain: A critical review of the literature on signaling unobservable product quality. Journal of Marketing, 64(2), 66-79.

Klein, A. (2002). Audit committee, board of director characteristics, and earnings management. Journal of Accounting and Economics, 33(3), 375-400.

Kothari, S.P., Leone, A.J., \& Wasley, C.E. (2005). Performance matched discretionary accruals measures, Journal of Accounting and Economics, 39(1), 163-197.

Krishnan, J. \& Schauer, P. (2000). "The differentiation of quality among auditors: evidence from the not-for-profit sector", Auditing: A Journal of Practice and Theory, 19(2), 9-25.

Leuz, C., Nand, D. \& Wysocki, P.D. (2003). Earnings Management and Investor Protection: An International Comparison. Journal of Financial Economics, 69(3), 505-27.

Levitt, A. (2000). "Renewing the covenant with investors". Speech before the New York University Center for Law and Business, http://www.rutgers.edu/accounting.

Marra, A., Mazzola, P., \& Prencipe, A. (2011). Board monitoring and earnings management pre and post-IFRS. The International Journal of Accounting, 46(2), 205-230.

Mgbame, C.O., Eragbhe, E.N. \& Osazuwa, N.P. (2012). Audit Partner Tenure and Audit Quality: An Empirical Analysis European Journal of Business and Management 4(7), 154-162, ISSN 2222-1905 (Paper) ISSN 2222-2839 (Online).

Mollik, A., Mir, M., Mclevr, R. et al. (2013). Earnings Management during the Global Financial Crisis: An Empirical Analysis of Australian Companies. Proceedings of 9th Asian Business Research Conference 20-21 December, 2013, BIAM Foundation, Dhaka, Bangladesh ISBN: 978-1-922069-39-9.

Myers, J.N., Myers, L.A., \& Omer, T.C. (2003). Exploring the term of the auditor-client relationship and the quality of earnings: A case for mandatory auditor rotation. The Accounting Review 78(3), 779-799.

Nam, L. (2014). Earnings Management and Audit Fee Responses in New Zealand Financial Markets \& Corporate Governance Conference. http://dx.doi.org/10.2139/ ssrn.2388579.

Naz, I., Bhatti, K., Ghafoor, A. et al. (2011). Impact of firm size and capital structure on earnings management: Evidence from Pakistan. International Journal of Contemporary Business Studies, 2(12), 22-31.

Nuraddeen, H. (2015). Examined the Impact of Audit Committee and Audit Quality on Preventing Earnings Management in the Pre- and Post- Nigerian Corporate Governance Code 2011 procedia - Social and Behavioral Sciences 172(2015), 651657.

Okolie, A.O., Izedonmi, F.O., \& Enofe, A.O. (2013). Audit Quality and Accrual - Based Earnings Management of Quoted Companies in Nigeria. IOSR Journal of Economics and Finance 2(2), 07-16.

Olabisi, J., Agbatogun, T.O., \& Akinrinola, T.O. (2017). Audit quality and earnings management among Nigerian listed deposit money banks pyrex journal of taxation and accounting management 1(1), 1-8. 
Onalo, U., Mohd, L., \& Ahmad, K. (2013). Corporate governance and earnings management: empirical evidence from Malaysian and Nigerian banks Asian journal of management sciences \& education 2(4) ISSN: 2186-845X ISSN: 2186-8441 Print.

Park, W.Y., and Shin, H.H. (2003). Board composition and earnings management in Canada. Journal of Corporate Finance, 10(3), 431-457 doi:10.1016/S0929-119 (03) 00025-7.

Patrick, B., Dain, C., \& Matthew, E. (2013). Audit Committee Financial Expertise and Earnings Management: The Role of Status Journal of Accounting and Economics 58(2-3) https://doi.org/10.1016/j.jacceco.2014.08.006.

Roychowdhury, S. (2006). Earnings management through real activities manipulation journal of Accounting and Economics, 42(2006), 335-370.

Sankar, M.R. \& Subramanyam, K.R. (2001). 'Reporting Discretion and Private Information communication through Earnings', Journal of Accounting Research, 39(2), 365-386.

Schipper, K. (1989). 'Commentary on earnings management', Accounting Horizons, 3(4), 91-102.

Seyyed, A.M., Mahdi, M., \& Mohsen, K. (2012). An Investigation into the Relationship between Audit Committee and Audit Quality. Australian Journal of Basic and Applied Sciences 6(10), 409-416.

Simon, D., Ann, G. \& Marleen, W. (2014). Audit partners' economic incentives and accrualsbased earnings management. https://www.isarhq.org/2014_downloads/papers/ISAR 2014_Dekeyser_Gaeremynck_Willekens.pdf.

Song, J. \& Windram, B. (2000). The Effectiveness of Audit Committee: Experience from UK, Working Paper.12th Asian-Pacific Conference on International Accounting Issues. Beijing. China 21-24.

Steven, M., \& Mussie, T. (2016). Examined the relationship between audit fees and earnings quality of financial institutions Journal of Accounting and Finance 16(5).

Sun, J., \& Liu, G. (2013), "Auditor industry specialization, board governance, and earnings management Managerial Auditing Journal, 28(1), 45-64. https://doi.org/10.1108/02 686901311282498

Teoh, S., Welch, I., \& Wong, T. (1998). Earnings Management and the Long-Run Market Performance of Initial Public Offerings. Journal of Finance, 53(6), 1935-1974.

Walker, P., Lewis, B., \& Casterella, J. (2001). Mandatory Sun auditor rotation: Arguments and current evidence. Accounting Enquiries 10(Spring/Summer), 209-242.

Watkins, A.L., Hillison, W., \& Morecroft, S.E. (2004). Audit quality: a synthesis of theory and empirical evidence, Journal of Accounting Literature, 23,153-193.

Weerapong, K., Shraddha, V., \& Keith, A. (2015). Earnings Management and Audit Quality: Evidence from Southeast Asia.

Yaping, N. (2005). The Theoretical Framework of Earnings Management. Canadian Social Science, 1(3), 2-38.

Zehri, F., \& Shabou, R. (2011). Audit Quality, Corporate Governance and Earnings Management in the Context of Tunisian Firms. Journal of Administrative \& Economics Science, 1(1).

Zuo, L., \& Guan, X. (2014). The Association of Audit Firm Size and Industry Specialization on Earnings Management: Evidence in China The Macrotheme Review 3(7), 1-21. 
Appendix 1. Descriptive Statistics

\begin{tabular}{|c|c|c|c|c|c|c|c|}
\hline & AUDTE & AUDFS & AUCID & FLACM & AUDFE & MJONEMODEL & $\begin{array}{c}\text { PERF } \\
\text { MODEL }\end{array}$ \\
\hline Mean & 0.311258 & 0.629139 & 0.682119 & 0.781457 & 172630.0 & 25771676 & $-1.11 \mathrm{E}+08$ \\
\hline Median & 0.000000 & 1.000000 & 1.000000 & 1.000000 & 14000.00 & $-2.90 \mathrm{E}+09$ & -618002.0 \\
\hline Maximum & 1.000000 & 1.000000 & 1.000000 & 1.000000 & 6800000. & $7.70 \mathrm{E}+10$ & $3.23 \mathrm{E}+10$ \\
\hline Minimum & 0.000000 & 0.000000 & 0.000000 & 0.000000 & 12.00000 & $-3.65 \mathrm{E}+09$ & $-2.60 \mathrm{E}+10$ \\
\hline Std. Dev. & 0.464549 & 0.484643 & 0.467202 & 0.414633 & 874431.8 & $1.18 \mathrm{E}+10$ & $4.65 \mathrm{E}+09$ \\
\hline Skewness & 0.815285 & -0.534698 & -0.782210 & -1.362138 & 6.945741 & 4.518157 & 0.574200 \\
\hline Kurtosis & 1.664689 & 1.285902 & 1.611853 & 2.855419 & 50.52290 & 23.85459 & 31.74129 \\
\hline & & & & & & & \\
\hline Jarque-Bera & 27.94640 & 25.68095 & 27.52204 & 46.82622 & 15423.39 & 3250.081 & 5205.603 \\
\hline Probability & 0.000001 & 0.000003 & 0.000001 & 0.000000 & 0.000000 & 0.000000 & 0.000000 \\
\hline & & & & & & & \\
\hline Sum & 47.00000 & 95.00000 & 103.0000 & 118.0000 & 26067136 & $3.89 \mathrm{E}+09$ & $-1.67 \mathrm{E}+10$ \\
\hline Sum Sq. Dev. & 32.37086 & 35.23179 & 32.74172 & 25.78808 & $1.15 \mathrm{E}+14$ & $2.08 \mathrm{E}+22$ & $3.24 \mathrm{E}+21$ \\
\hline & & & & & & & \\
\hline Observations & 151 & 151 & 151 & 151 & 151 & 151 & 151 \\
\hline
\end{tabular}

Appendix 2. Regression Result of Modified Jones Model

Dependent Variable: MODIFIEDJONEMODEL

Method: Panel Least Squares

Date: 05/30/17 Time: 21:55

Sample: 20122015

Periods included: 4

Cross-sections included: 38

Total panel (unbalanced) observations: 151

\begin{tabular}{crlrr}
\hline \hline \multicolumn{1}{c}{ Variable } & Coefficient & \multicolumn{1}{c}{ Std. Error } & t-Statistic & Prob. \\
\hline C & $-3.64 \mathrm{E}+09$ & $2.54 \mathrm{E}+09$ & -1.430655 & 0.1547 \\
AUDTE & $-1.61 \mathrm{E}+09$ & $2.07 \mathrm{E}+09$ & -0.775789 & 0.4391 \\
AUDFS & $4.51 \mathrm{E}+09$ & $2.01 \mathrm{E}+09$ & 2.245478 & 0.0263 \\
AUCID & $-2.28 \mathrm{E}+09$ & $2.11 \mathrm{E}+09$ & -1.084353 & 0.2800 \\
AUDFEE & $3.63 \mathrm{E}+09$ & $2.35 \mathrm{E}+09$ & 1.548502 & 0.1237 \\
FINLITAUDCOMMEM & 268.9848 & 1104.442 & 0.243548 & 0.8079 \\
\hline \hline R-squared & 0.061266 & Mean dependent var & & 25771676 \\
Adjusted R-squared & 0.028896 & S.D. dependent var & & $1.18 \mathrm{E}+10$ \\
S.E. of regression & $1.16 \mathrm{E}+10$ & Akaike info criterion & & 49.22834 \\
Sum squared resid & $1.96 \mathrm{E}+22$ & Schwarz criterion & & 49.34823 \\
Log likelihood & -3710.739 & Hannan-Quinn criter. & & 49.27704 \\
F-statistic & 1.892672 & Durbin-Watson stat & & 0.517926 \\
Prob(F-statistic) & 0.099084 & & & \\
\hline
\end{tabular}

Dependent Variable: MODIFIEDJONEMODEL

Method: Panel Least Squares

Date: 05/30/17 Time: 21:58

Sample: 20122015

Periods included: 4

Cross-sections included: 38

Total panel (unbalanced) observations: 151 


\begin{tabular}{|c|c|c|c|c|}
\hline Variable & Coefficient & Std. Error & t-Statistic & Prob. \\
\hline $\mathrm{C}$ & -98454474 & $2.44 \mathrm{E}+09$ & -0.040288 & 0.9679 \\
\hline AUDTE & $1.98 \mathrm{E}+08$ & $1.34 \mathrm{E}+09$ & 0.147417 & 0.0883 \\
\hline AUDFS & -45120308 & $2.75 \mathrm{E}+09$ & -0.016411 & 0.9869 \\
\hline AUCID & 90358262 & $1.70 \mathrm{E}+09$ & 0.053081 & 0.9578 \\
\hline FINLITAUDCOMMEM & 6366501. & $1.82 \mathrm{E}+09$ & 0.003492 & 0.9972 \\
\hline AUDFEE & 140.9744 & 1354.131 & 0.104107 & 0.9173 \\
\hline \multicolumn{5}{|c|}{ Effects Specification } \\
\hline \multicolumn{5}{|c|}{ Cross-section fixed (dummy variables) } \\
\hline R-squared & 0.771224 & Mean dependent var & & 25771676 \\
\hline Adjusted R-squared & 0.682256 & S.D. dependent var & & $1.18 \mathrm{E}+10$ \\
\hline S.E. of regression & $6.65 \mathrm{E}+09$ & Akaike info criterion & & 48.30661 \\
\hline Sum squared resid & $4.77 \mathrm{E}+21$ & Schwarz criterion & & 49.16584 \\
\hline Log likelihood & -3604.149 & Hannan-Quinn criter. & & 48.65567 \\
\hline F-statistic & 8.668534 & Durbin-Watson stat & & 2.226689 \\
\hline Prob(F-statistic) & 0.000000 & & & \\
\hline
\end{tabular}

Dependent Variable: MODIFIEDJONEMODEL

Method: Panel EGLS (Cross-section random effects)

Date: 05/30/17 Time: 21:59

Sample: 20122015

Periods included: 4

Cross-sections included: 38

Total panel (unbalanced) observations: 151

Swamy and Arora estimator of component variances

\begin{tabular}{|c|c|c|c|c|}
\hline Variable & Coefficient & Std. Error & t-Statistic & Prob. \\
\hline $\mathrm{C}$ & $-1.52 \mathrm{E}+09$ & $2.69 \mathrm{E}+09$ & -0.567314 & 0.5714 \\
\hline AUDTE & $-1.15 \mathrm{E}+08$ & $1.32 \mathrm{E}+09$ & -0.087237 & 0.9306 \\
\hline AUDFS & $1.86 \mathrm{E}+09$ & $2.23 \mathrm{E}+09$ & 0.835444 & 0.4048 \\
\hline AUCID & $-2.72 \mathrm{E}+08$ & $1.62 \mathrm{E}+09$ & -0.168015 & 0.8668 \\
\hline FINLITAUDCOMMEM & $7.32 \mathrm{E}+08$ & $1.75 \mathrm{E}+09$ & 0.419563 & 0.6754 \\
\hline AUDFEE & 32.56235 & 1152.270 & 0.028259 & 0.9775 \\
\hline \multicolumn{5}{|c|}{ Effects Specification } \\
\hline & & & S.D. & Rho \\
\hline Cross-section random & & & $9.94 \mathrm{E}+09$ & 0.6912 \\
\hline Idiosyncratic random & & & $6.65 \mathrm{E}+09$ & 0.3088 \\
\hline \multicolumn{5}{|c|}{ Weighted Statistics } \\
\hline R-squared & 0.006140 & Mean dependent var & & 5703869. \\
\hline Adjusted R-squared & -0.028131 & S.D. dependent var & & $6.53 \mathrm{E}+09$ \\
\hline S.E. of regression & $6.62 \mathrm{E}+09$ & Sum squared resid & & $6.35 \mathrm{E}+21$ \\
\hline F-statistic & 0.179155 & Durbin-Watson stat & & 1.496535 \\
\hline Prob(F-statistic) & 0.970061 & & & \\
\hline
\end{tabular}


Unweighted Statistics

\begin{tabular}{lclr}
\hline \hline R-squared & 0.031061 & Mean dependent var & 25771676 \\
Sum squared resid & $2.02 \mathrm{E}+22$ & Durbin-Watson stat & 0.462091 \\
\hline \hline
\end{tabular}

Correlated Random Effects - Hausman Test

Equation: Untitled

Test cross-section random effects

\begin{tabular}{lcrr}
\hline \hline Test Summary & Chi-Sq. Statistic & Chi-Sq. d.f. & Prob. \\
\hline \hline Cross-section random & 3.936582 & 5 & 0.02586 \\
\hline \hline
\end{tabular}

Cross-section random effects test comparisons:

\begin{tabular}{crrrr} 
Variable & Fixed & Random & Var(Diff.) & Prob. \\
\hline \hline AUDTE & 198119831.807685 & -115045762.057605 & 67019689357062400 & 0.2264 \\
AUDFS & -45120307.800260 & 1864596236.019051 & 2577643510246010000 & 0.2343 \\
AUCID & 90358262.195768 & -272291505.091962 & 271212665053457410 & 0.4862 \\
FINLITAUDCOMMEM & 6366500.835658 & 732468137.524512 & 277054267378825220 & 0.1677 \\
AUDFEE & 140.974352 & 32.562351 & 505945.237296 & 0.8789 \\
\hline \hline
\end{tabular}

Cross-section random effects test equation:

Dependent Variable: MODIFIEDJONEMODEL

Method: Panel Least Squares

Date: 05/30/17 Time: 22:01

Sample: 20122015

Periods included: 4

Cross-sections included: 38

Total panel (unbalanced) observations: 151

\begin{tabular}{crrrr}
\hline \hline Variable & Coefficient & Std. Error & t-Statistic & Prob. \\
\hline \hline C & -98454474 & $2.44 \mathrm{E}+09$ & -0.040288 & 0.9679 \\
AUDTE & $1.98 \mathrm{E}+08$ & $1.34 \mathrm{E}+09$ & 0.147417 & 0.8831 \\
AUDFS & -45120308 & $2.75 \mathrm{E}+09$ & -0.016411 & 0.9869 \\
AUCID & 90358262 & $1.70 \mathrm{E}+09$ & 0.053081 & 0.9578 \\
FINLITAUDCOMMEM & 6366501. & $1.82 \mathrm{E}+09$ & 0.003492 & 0.9972 \\
AUDFEE & 140.9744 & 1354.131 & 0.104107 & 0.9173 \\
\hline \hline
\end{tabular}

Cross-section fixed (dummy variables)

\begin{tabular}{llll}
\hline \hline R-squared & 0.771224 & Mean dependent var & 25771676 \\
Adjusted R-squared & 0.682256 & S.D. dependent var & $1.18 \mathrm{E}+10$ \\
S.E. of regression & $6.65 \mathrm{E}+09$ & Akaike info criterion & 48.30661 \\
Sum squared resid & $4.77 \mathrm{E}+21$ & Schwarz criterion & 49.16584 \\
Log likelihood & -3604.149 & Hannan-Quinn criter. & 48.65567 \\
F-statistic & 8.668534 & Durbin-Watson stat & 2.226689 \\
Prob(F-statistic) & 0.000000 & &
\end{tabular}


Appendix 3. Regression Result of Performance Model

Dependent Variable: PERFORMANCEMODEL

Method: Panel Least Squares

Date: 05/30/17 Time: 22:56

Sample: 20122015

Periods included: 4

Cross-sections included: 38

Total panel (unbalanced) observations: 151

\begin{tabular}{ccccc}
\hline \hline \multicolumn{1}{c}{ Variable } & Coefficient & Std. Error & t-Statistic & Prob. \\
\hline C & $-4.67 \mathrm{E}+08$ & $1.02 \mathrm{E}+09$ & -0.457759 & 0.6478 \\
AUDTE & $-3.81 \mathrm{E}+08$ & $8.32 \mathrm{E}+08$ & -0.457297 & 0.6481 \\
AUDFS & $-3.98 \mathrm{E}+08$ & $8.06 \mathrm{E}+08$ & -0.493805 & 0.6222 \\
AUCID & $1.62 \mathrm{E}+09$ & $8.45 \mathrm{E}+08$ & 1.917619 & 0.0571 \\
AUDFEE & $-4.34 \mathrm{E}+08$ & $9.41 \mathrm{E}+08$ & -0.461317 & 0.6453 \\
FINLITAUDCOMMEM & -236.0322 & 443.1628 & -0.532608 & 0.5951 \\
\hline \hline R-squared & 0.026654 & Mean dependent var & & $-1.11 \mathrm{E}+08$ \\
Adjusted R-squared & -0.006910 & S.D. dependent var & & $4.65 \mathrm{E}+09$ \\
S.E. of regression & $4.66 \mathrm{E}+09$ & Akaike info criterion & & 47.40202 \\
Sum squared resid & $3.15 \mathrm{E}+21$ & Schwarz criterion & & 47.52191 \\
Log likelihood & -3572.852 & Hannan-Quinn criter. & & 47.45072 \\
F-statistic & 0.794133 & Durbin-Watson stat & & 0.901585 \\
Prob(F-statistic) & 0.555545 & & \\
\hline \hline
\end{tabular}

Dependent Variable: PERFORMANCEMODEL

Method: Panel Least Squares

Date: 05/30/17 Time: 22:59

Sample: 20122015

Periods included: 4

Cross-sections included: 38

Total panel (unbalanced) observations: 151

\begin{tabular}{crrrr}
\hline \hline Variable & Coefficient & Std. Error & t-Statistic & Prob. \\
\hline \hline C & $-1.79 \mathrm{E}+08$ & $1.15 \mathrm{E}+09$ & -0.155764 & 0.8765 \\
AUDTE & $2.32 \mathrm{E}+08$ & $6.30 \mathrm{E}+08$ & 0.368453 & 0.7133 \\
AUDFS & -22999120 & $1.29 \mathrm{E}+09$ & -0.017838 & 0.9858 \\
AUCID & 64897246 & $7.98 \mathrm{E}+08$ & 0.081297 & 0.9354 \\
FINLITAUDCOMMEM & -56984856 & $8.55 \mathrm{E}+08$ & -0.066642 & 0.9470 \\
AUDFEE & 60.50103 & 635.0213 & 0.095274 & 0.9243 \\
\hline \hline
\end{tabular}

Effects Specification

Cross-section fixed (dummy variables)

\begin{tabular}{lrlr}
\hline \hline R-squared & 0.675997 & Mean dependent var & $-1.11 \mathrm{E}+08$ \\
Adjusted R-squared & 0.549996 & S.D. dependent var & $4.65 \mathrm{E}+09$ \\
S.E. of regression & $3.12 \mathrm{E}+09$ & Akaike info criterion & 46.79210 \\
Sum squared resid & $1.05 \mathrm{E}+21$ & Schwarz criterion & 47.65132 \\
Log likelihood & -3489.803 & Hannan-Quinn criter. & 47.14116 \\
F-statistic & 5.365007 & Durbin-Watson stat & 2.289311 \\
Prob(F-statistic) & 0.000000 & & \\
\hline
\end{tabular}


Dependent Variable: PERFORMANCEMODEL

Method: Panel EGLS (Cross-section random effects)

Date: 05/30/17 Time: 23:01

Sample: 20122015

Periods included: 4

Cross-sections included: 38

Total panel (unbalanced) observations: 151

Swamy and Arora estimator of component variances

\begin{tabular}{|c|c|c|c|c|}
\hline Variable & Coefficient & Std. Error & t-Statistic & Prob. \\
\hline $\mathrm{C}$ & $-2.86 \mathrm{E}+08$ & $1.12 \mathrm{E}+09$ & -0.254763 & 0.7993 \\
\hline AUDTE & $1.18 \mathrm{E}+08$ & $6.13 \mathrm{E}+08$ & 0.192579 & 0.8476 \\
\hline AUDFS & -96086526 & $9.61 \mathrm{E}+08$ & -0.099964 & 0.9205 \\
\hline AUCID & $4.77 \mathrm{E}+08$ & $7.41 \mathrm{E}+08$ & 0.643585 & 0.5209 \\
\hline FINLITAUDCOMMEM & $-1.51 \mathrm{E}+08$ & $8.01 \mathrm{E}+08$ & -0.188236 & 0.8510 \\
\hline AUDFEE & -44.89707 & 503.7203 & -0.089131 & 0.9291 \\
\hline \multicolumn{5}{|c|}{ Effects Specification } \\
\hline & & & S.D. & Rho \\
\hline Cross-section random & & & $3.61 \mathrm{E}+09$ & 0.5735 \\
\hline Idiosyncratic random & & & $3.12 \mathrm{E}+09$ & 0.4265 \\
\hline \multicolumn{5}{|c|}{ Weighted Statistics } \\
\hline R-squared & 0.003363 & Mean dependent var & & -43743017 \\
\hline Adjusted R-squared & -0.031004 & S.D. dependent var & & $3.05 \mathrm{E}+09$ \\
\hline S.E. of regression & $3.09 \mathrm{E}+09$ & Sum squared resid & & $1.39 \mathrm{E}+21$ \\
\hline F-statistic & 0.097848 & Durbin-Watson stat & & 1.636798 \\
\hline $\operatorname{Prob}($ F-statistic) & 0.992361 & & & \\
\hline \multicolumn{5}{|c|}{ Unweighted Statistics } \\
\hline R-squared & 0.011628 & Mean dependent var & & $-1.11 \mathrm{E}+08$ \\
\hline Sum squared resid & $3.20 \mathrm{E}+21$ & Durbin-Watson stat & & 0.850264 \\
\hline
\end{tabular}

Correlated Random Effects - Hausman Test

Equation: Untitled

Test cross-section random effects

\begin{tabular}{lrrr}
\hline \hline Test Summary & Chi-Sq. Statistic & Chi-Sq. d.f. & Prob. \\
\hline \hline Cross-section random & 3.198182 & 5 & 0.0695 \\
\hline \hline
\end{tabular}

Cross-section random effects test comparisons:

\begin{tabular}{crrrr} 
Variable & Fixed & Random & Var(Diff.) & Prob. \\
\hline \hline AUDTE & 232215408.621981 & 118018006.367111 & 216474933775869056 & 0.4377 \\
AUDFS & -22999119.903301 & -96086525.830437738390526353929130 & 0.9322 \\
AUCID & 64897245.921276 & 476956815.892685 & 88027052262781950 & 0.1649 \\
FINLITAUDCOMMEM & -56984855.747965 & -150720226.510407 & 90059349787132550 & 0.7548 \\
AUDFEE & 60.501035 & -44.897069 & 149517.906547 & 0.7852 \\
\hline \hline
\end{tabular}


Cross-section random effects test equation:

Dependent Variable: PERFORMANCEMODEL

Method: Panel Least Squares

Date: 05/30/17 Time: 23:05

Sample: 20122015

Periods included: 4

Cross-sections included: 38

Total panel (unbalanced) observations: 151

\begin{tabular}{|c|c|c|c|c|}
\hline Variable & Coefficient & Std. Error & t-Statistic & Prob. \\
\hline $\mathrm{C}$ & $-1.79 \mathrm{E}+08$ & $1.15 \mathrm{E}+09$ & -0.155764 & 0.8765 \\
\hline AUDTE & $2.32 \mathrm{E}+08$ & $6.30 \mathrm{E}+08$ & 0.368453 & 0.7133 \\
\hline AUDFS & -22999120 & $1.29 \mathrm{E}+09$ & -0.017838 & 0.9858 \\
\hline AUCID & 64897246 & $7.98 \mathrm{E}+08$ & 0.081297 & 0.9354 \\
\hline FINLITAUDCOMMEM & -56984856 & $8.55 \mathrm{E}+08$ & -0.066642 & 0.9470 \\
\hline AUDFEE & 60.50103 & 635.0213 & 0.095274 & 0.9243 \\
\hline \multicolumn{5}{|c|}{ Effects Specification } \\
\hline \multicolumn{5}{|c|}{ Cross-section fixed (dummy variables) } \\
\hline R-squared & 0.675997 & Mean dependent var & & $1.11 \mathrm{E}+08$ \\
\hline Adjusted R-squared & 0.549996 & S.D. dependent var & & 4.65E+09 \\
\hline S.E. of regression & $3.12 \mathrm{E}+09$ & Akaike info criterion & & 46.79210 \\
\hline Sum squared resid & $1.05 \mathrm{E}+21$ & Schwarz criterion & & 47.65132 \\
\hline Log likelihood & -3489.803 & Hannan-Quinn criter. & & 47.14116 \\
\hline F-statistic & 5.365007 & Durbin-Watson stat & & 2.289311 \\
\hline Prob(F-statistic) & 0.000000 & & & \\
\hline
\end{tabular}


